\title{
Determinants of Management of Central Bank to Provide the Economic Growth: An Application of Structural Equation Modeling
}

\author{
LARYSA SYSOYEVA*1, INNA BIELOVA ${ }^{2}$, LUIDMILA RYABUSHKA ${ }^{3}$, OLEKSII DEMIKHOV ${ }^{4}$ \\ ${ }^{1,2,3}$ Department of Banking, Finance and Insurance, Sumy State University, UKRAINE. \\ *E-mail: I.sysoieva@uabs.sumdu.edu.ua \\ ${ }^{4}$ Department of Management, Sumy State University, UKRAINE.
}

\begin{abstract}
The country's domestic economic expansion is becoming increasingly important, especially in the context of the epidemic and financial crises, both within individual countries and the world. To provide this growth, it is relevant to the strategy of the central bank's activities for overcoming extern in the context of epidemical and internal threats with specific regulatory approaches and monetary instruments. The paper summarizes the arguments and counterarguments within the discussion of the question regarding the central bank's influence on the country's economic growth. The study's primary purpose is to determine the relationship between the indicators that characterize the central bank's activities and the country's economic development. The systematization of literary sources and approaches related to this issue confirms the mediated relationship between the activities of the central bank and the economic growth on a long-term basis. The relevance of this topic is closely connected with the changing role of the central bank and the expansion of its powers, tasks, responsibilities, and its place in the country's economy. This research's objective is the economies of the countries predominantly of the European Union, which has different levels of economic development. The structural modeling method is used in STATA 12.0 (based on data on 11 variables for the period of 1998-2016 for 24 countries). The results of the study confirm the correlation between the role of central banks and domestic economic expansion.
\end{abstract}

Key words: monetary policy, financial stability; economic growth; structural modeling method.

JEL classification: $\mathrm{C} 15, \mathrm{C} 87, \mathrm{E} 5, \mathrm{O} 1$

Received: 20 March 2021

Accepted: 2 April 2021 


\section{Introduction.}

The central bank is an independent national monetary policy institution that regulates the banking sector and provides financial services. The central bank's main tasks for most countries are stereotyped and aimed at ensuring the stability of the national currency, the implementation of monetary policy, and management of gold and currency reserves. However, most European countries' rapid economic development, which has been observed over the past decades, has substantially transformed the central bank's role, expanding its functions and powers. Performing several traditional tasks that directly impact the banking sector, today, the central bank's activity is aimed at promoting and supporting the growth of production, employment, and real incomes. With monetary instruments' help, the regulatory influences both on the banking sector and the country's development in general. The purpose of our study is to determine the relationship between latent variables that characterize the spheres of the economy and the banking sector, their impact, and their role in the country's economic development.

To achieve the aim, data for the period of 1998-2016 for the following 24 countries were used: Belgium, Czech Republic, Denmark, Finland, France, Georgia, Germany, Greece, Hungary, Iceland, Ireland, Italy, Netherlands, Poland, Portugal, the Russian Federation, Slovenia, Spain, Switzerland, Sweden, Turkey, the United Kingdom, Ukraine.

\section{Literature Review.}

The increase in the number of banking and financial crises in recent years has led to the intensification of researching the leading causes of problems and their impact on the real economy. Scientific works in this area are concentrated in two main directions: first, understanding the connections between indicators of the banking sector and economic growth and second, in the quantification of costs from banking sector crises in terms of actual GDP losses. In the first director of the research, R. Levine [28] demonstrates the connection between the banking sector's openness and economic growth. R. Levine (1997), R. King (1993a), and A.Demirguc-Kunt (1998) emphasized that the degree of development of the financial sector was an essential factor in economic growth.

In the scientific literature, the position as to whether the banking sector is the main trigger for the economic downturn is ambiguous and less investigated since it is difficult to separate the causal connection between the real economy and the financial sector. Ambiguous conclusions have raised interest both from the government and academics concerning the banking system's interdependence and the economy (Hilbers et al., 2005; Kaminsky et al., 1999).

Most modern central banks have identified monetary stability as their primary goal for long-term economic growth and full employment. As a rule, this task's realization is related to the targeting of the consumer price index, which makes indicators such as interest rates, money supply, and exchange rate equally important (Ben et al., 1997; Borio, 1997; Dominquez et al., 2006).

Saymeh and Orabi (2013) observed the impact of interest rates, inflation rate, and GDP on Jordan's real economic growth throughout 2000-2010 through financial econometrics. The Johansen Cointegration Test results confirmed that all variables are related in the long-term perspective. The results of regression tests indicate that interest rates and inflation rates were shocking for economic growth. Semuel and Nurina (2015) investigated the impact of inflation, interest rates, and exchange rates on Indonesia's gross domestic product based on monthly data for the period of 2005-2013 by the statistical analysis method. The results have shown that there is an inverse relationship between interest rates and GDP and a direct connection between exchange rates and GDP.

There are two opposed views of scholars who have tried to assess the relationship between exports and economic growth. According to the opinions of the first group, exportation is considered to positively affect economic growth, while others indicate an absolute lack of connection. For example, Berg and Schmidt (1994), Onafowora et al. (1996), Giles et al. (1992) suggest that growth in 
exports stimulates economic growth. Most of them emphasize that the development of exports may reflect the change of demand for the country's products, which will be reflected in economic growth.

Out of the few studies that tried to analyze the connection between money supply and economic growth, the results are ambiguous. Some studies have shown a positive relationship between money supply and economic development, while others have shown a slight correlation between these variables. Hussain and Haque (2017) investigated the empirical analysis of the relationship between money supply and GDP growth per capita in Bangladesh using the Vector Error Correction Model (VECM). As a result of the research, it was discovered that the money supply plays a significant role in the country's economic growth. Ogunmuyiwa and Ekone (2010) reviewed the relationship between money supply and economic development for Nigeria using the error correction model from 1920 to 2006. The results of their research indicate that money supply directly influences economic growth. Another investigation is focused on money supply, inflation, and economic growth: the authors (Kaminsky and Reinhart, 1999) have found the steady dependence between money supply and economic development for Nigeria in the period of 1975-2008.

Evidence in Fields (1989) shows that rising per capita income generally leads to a reduction in poverty. Some studies tried to quantify the rate of economic growth rate to the change in poverty due to the idea of increasing the elasticity in poverty. Elasticity in poverty estimates the percentage change in poverty caused by the one-percent change in per capita income. In this regard, Ravallion and Chen (1997) conducted a country-based regression analysis between countries based on a sample of 62 developing countries. The same conclusion was obtained by other research using various methodological techniques (Deininger and Klaus, 1996a, Roemer et al., 1997, Gallup and Jeffrey, 1998a).

Adams' study (2002) compares the experience of a wide range of developing countries and confirms the assumption that fast and sustainable growth is the most important way of reducing poverty. Based on the calculations, the author concluded that an increase of $10 \%$ of the country's average income would reduce the poverty rate from $20 \%$ to $30 \%$.

There is a large number of authors who investigated the problem of the relationship between unemployment and economic growth. The theoretical review, which lies at the heart of our study, includes the theory of Keynesian unemployment, the Marxist theory of unemployment, and Oaken's unemployment theory. Kemi and Dayo (2014) believed that the gross domestic product's growth rate in the economy causes an increase in employment and a decrease in unemployment. Okun's law (Okun, 1962) aims to explain the relationship between unemployment and economic growth in the economy. The theory argues that unemployment had a negative correlation with economic growth in any economy. According to the idea, the decline in the unemployment rate by $1 \%$ leads to economic growth by $3 \%$. The theories mentioned above explain the relationship between unemployment and economic growth in the process of development.

Determining the impact of foreign direct investment on the country's economic growth is a challenge. The interdependence between economic growth and the volume of foreign direct investments in the country can be traced using macroeconomic indicators, such as GDP growth rate, the importance of investment, and exchange rate dynamics. Zhang et al. (2001) and Choe (2003) investigated the relationship between economic growth and foreign direct investment. The authors considered several developing countries, including Latin America and East Asia. Zhang et al. (2001) discovered that research shows that FDI stimulates economic growth in many cases. Still, two conditions have the maximum effect - macroeconomic stability and the existence of a free trade regime. Choe (2003), Straßberger (2016) examined the cause-effect relationship between direct investment and economic growth under different conditions. He discovered that an increase in foreign direct investment was due to economic growth.

Numerous studies are aimed at identifying and analyzing the relationship between economic growth and the current account deficit. Debelle and Faruqee (2009) noted that countries with rapid economic growth tend to have a high current account deficit, while Calderon et al. (2000), in their 
studies, found that the development of the GDP in developing countries has led to an increase of the current account deficit. Exploring the United States, Kandil and Greene (2002) have confirmed that the current account deficit correlates with real GDP growth in the long-term perspective and that the relationship is reversed and strong.

The sustainability of economic growth depends on the exchange rate, which is confirmed by several studies. Kogid et al. (2012) tried to investigate the impact of exchange rates on Malaysia's economic growth using time series data covering 1971-2009. The test results show a long-term cointegration between nominal and real exchange rates and economic development. Chen (2012) studied the real exchange rate in economic growth and convergence of growth rates between China's provinces using data from 28 Chinese areas from 1992 to 2008. The results confirm the positive effect of increasing the real exchange rate on economic growth in the regions.

Kumar and Woo (2010) explore the impact of high governmental debt on long-term economic development, based on data from advanced and new economies for nearly four decades. Empirical results suggest that, on average, with a $10 \%$ increase in debt, the country's growth rate is reduced by $1 \%$. A group of empirical studies examine the impact of various levels of public debt on economic growth more closely and believe that this negative connection exists only after a specific limit. Smyth and Hsing (1995) argue that the optimal debt ratio of the state is $38.4 \%$. Pattillo et al. (2002), using the large datasheet from 93 developing countries from 1969 to 1998, concludes that the negative impact of external debt on GDP growth exists only when the current debt cost exceeds $35-40 \%$ of GDP.

A wide range of practical studies analyzes the relationship between inflation and economic growth in the context of both developing and developed countries. Khan and Abdelhak (2001) researched to study the development and inflation relationship. They used sample data from 140 developing countries and developed countries, covering the period from 1960 to 1998 . Their conclusions have shown that rising inflation above a certain threshold significantly impairs economic growth. The study argued that the size of the point depends on the level of the country's development (for example, for developing countries, it is 7-11\%, and for developed countries - 1-3\%). Sweidan (2004) investigated the relationship between inflation and economic growth in Jordan for 1970-2003. The result discovered a significant positive relationship between the two studied variables.

Meanwhile, problem loans are a significant problem for the banking sector in any country. The risk of non-performing loans is usually due to the deterioration of the foreign economic environment, for example, when economic depression occurs. Lawrence (1995) argued that low-income borrowers had higher default chances because of the increased risk of job loss and insolvency.

Present scientific studies confirm the relationship between economic growth and the development of the banking sector. McKinnon (1973) believes that the provided banking services' volume growth and the intensification of financial activity accelerate economic growth. Similarly, King and Levine (1993a) argued that infusion of bank funds into the economy stimulates the movement of "economic wheels." Based on empirical studies, the authors Rajan et al. (1998) conclude that the banking sector is concentrating its efforts on overall economic growth, contributing to the development of industries that are dependent on external financing. The research results of the abovementioned authors show the availability of the relationship and its nature between the actions of the central bank and the development of the economy. The literature review of these authors became the basis for the choice of indicators for further research in our work.

\section{Methodology.}

The information research base covers two groups of indicators that characterize the banking sector and the country's overall economic development. The selection of the period from 1998 to 2016 is based on financial, methodological, and practical considerations. On the one hand, according 
to the chosen methodology, this time series is sufficient to detect the dependencies between the indicators. On the other hand, for the study covered by this article, the period was chosen, taking into account the availability and comparability of the data in the selected countries. Table 1 shows the variables, five of which characterize central bank activities of the country and the rest of the indicators - the economy's state.

For improving the model's quality, a correlation analysis was previously conducted, which resulted in excluding the variables analyzed in the number of three (cut-off method). Out of the 14 initially formed indicators, foreign exchange reserves, foreign direct investment, and exchange rate were excluded.

Despite the reduction in the number of indicators, the available amount of data is sufficient to conduct the study. The structural modeling method involves at least 220 observations (11 variables * $20=220)$; in our case, $456(24$ countries*19 years $=456)$ are more than sufficient.

Structural modeling is a methodology that has become widely used in scientific works. Different researchers are increasingly using this approach to represent the interactions between other elements associated with one problem. Structural modeling or structural equation modeling (SEM) is a comprehensive and compelling technique for multidimensional analysis, which includes many methods from different fields of statistics.

\section{Demonstrations.}

In our study, the software complex STATA 12.0 is used since, in this system, the methods of modeling using the structural equations are fully implemented. The Structural modeling process consists of several stages: the description of a model that reflects the current dependence between variables in the author's opinion is made; - with the help of unique methods, the program determines which values of the dispersion and covariance data correspond to the initial model based on the input data; - the program checks how dispersion and covariance indicators satisfy the built-in model; - the program displays the results of statistical tests, as well as displays estimations of parameters and standard errors for coefficients in linear equations; based on the received data the decision is made about coordination of this model with the initial data.

For describing the relationship between two factors that characterize the state of the economy and the banking system, a path diagram was constructed using the STATA package.

Figure 1 shows a path diagram showing the relationship between the central bank's sphere of influence and the state of the economy and the impact of endogenous variables on them.

In STATA modules, you can calculate pair correlation coefficients to express the relationship between two variables (Table 2). In general, the Log-likelihood (maximum likelihood ratio) is -18522 , and $\chi 2=788.2$, which indicates the excellent quality of the SEM model.

Using equations, you can see the direction and impact of implicit variables. Thus, the growth of the Z-score and Broad money M3 (\% of GDP) directly affects the latent variable Bank and the NPL (\% to total gross loans), and the Interest rate (\%) has a reverse effect. It corresponds to the logic of existing research by different authors, as it was mentioned above.

As for the latent economic variable "Economy"; the growth of the debt load and the level of unemployment negatively affect the economy's state. For example, the indicator balance of payments in \% to GDP has a negative value for the absolute majority of observations, and the deterioration negatively affects the state of the economy.

The mutual influence between the latent variables corresponds to the equation:

$$
\text { Economy }=0.7634 \cdot \text { Bank }
$$

That is, improving the state of the banking sector (at the expense of the central bank indicators) causes the improvement of the economy for 24 European countries. 
Table 1. Groups of indicators and sources of analyzed data

\begin{tabular}{|c|c|c|}
\hline Indicators & Marking & Source \\
\hline \multicolumn{3}{|l|}{ Banking Sector (Bank) } \\
\hline Bank Z-score & Zscore & The World Bank \\
\hline $\begin{array}{l}\text { Nonperforming loans to total gross } \\
\text { loans (\%) }\end{array}$ & NPL & The World Bank \\
\hline Discount rate, Interest rate (\%) & Int. rate & $\begin{array}{l}\text { Bank for International } \\
\text { Settlements }\end{array}$ \\
\hline $\begin{array}{l}\text { Monetary aggregate M3 to GDP - } \\
\text { Broad money M3 }\end{array}$ & M3_GDP & $\begin{array}{l}\text { International Monetary Fund } \\
\text { The World Bank }\end{array}$ \\
\hline $\begin{array}{l}\text { Growth rate of foreign exchange } \\
\text { reserves }\end{array}$ & Exch_reserves & $\begin{array}{l}\text { International Monetary Fund } \\
\text { The World Bank }\end{array}$ \\
\hline \multicolumn{3}{|l|}{ Economic Development (Economy) } \\
\hline Growth rate of GDP, \% & GDP_growth & The World Bank \\
\hline $\begin{array}{l}\text { Export to GDP - Exports of goods } \\
\text { and services (\% of GDP) }\end{array}$ & Export_GDP & $\begin{array}{l}\text { Organization of economic } \\
\text { cooperation and development }\end{array}$ \\
\hline $\begin{array}{l}\text { Foreign direct investment, net } \\
\text { inflows (\% of GDP) }\end{array}$ & Invest_GDP & $\begin{array}{l}\text { International Monetary Fund } \\
\text { The World Bank }\end{array}$ \\
\hline Balance of payments to GDP & Balance. GDP & International Monetary Fund \\
\hline $\begin{array}{l}\text { Changing the currency exchange } \\
\text { rate to the dollar }\end{array}$ & Exch_rate & $\begin{array}{l}\text { Bank for International } \\
\text { Settlements }\end{array}$ \\
\hline $\begin{array}{l}\text { Unemployment rate, \% from total } \\
\text { labor force }\end{array}$ & Unempl & International Labor Organization \\
\hline $\begin{array}{l}\text { Poverty level - Poverty headcount } \\
\text { ratio at } \$ 5.50 \text { a day }(\% \text { of } \\
\text { population) }\end{array}$ & Poverty & The World Bank \\
\hline $\begin{array}{l}\text { External debt - Government gross } \\
\text { debt (\% of GDP) }\end{array}$ & Debt_GDP & International Monetary Fund \\
\hline Producer Price Index, $\%$ & PPI & $\begin{array}{l}\text { Bank for } \\
\text { Settlements }\end{array}$ \\
\hline
\end{tabular}

Figure 1. Path diagram in STATA

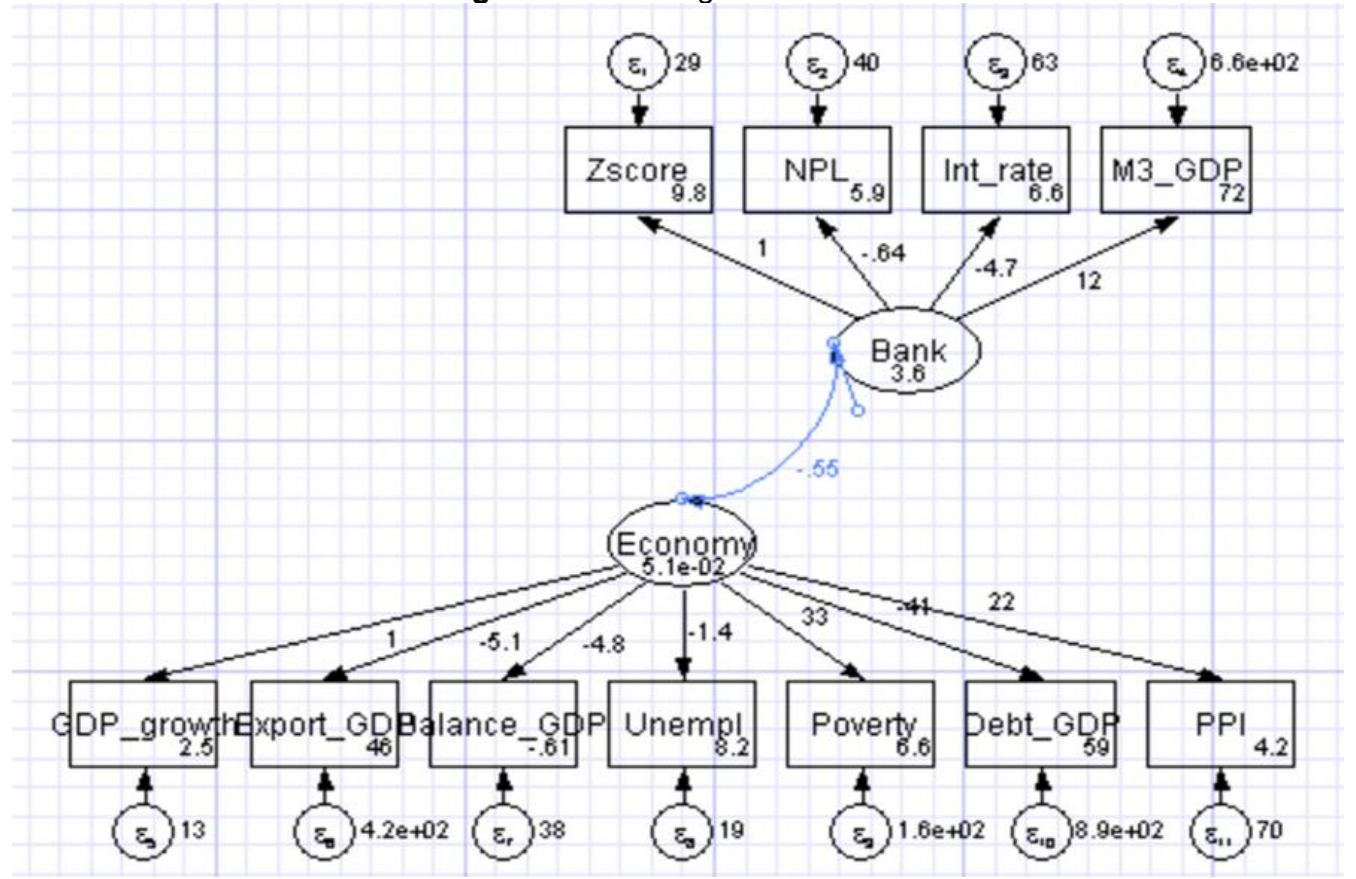


Table 2. SEM equation for 2 latent variables: "Bank" and "Economy"

\begin{tabular}{|l|l|}
\hline \multicolumn{1}{|c|}{ Banking Sector (Bank) } & \multicolumn{1}{c|}{ State of Economy (Economy) } \\
\hline Zscore $=$ Bank $+9,817$ & GDP_growth $=$ Economy $+2,516$ \\
$\mathrm{NPL}=-0,6454$ Bank $+5,877$ & Export_GDP $=-5,103$ Economy $+46,182$ \\
Int_rate $=-4,703$ Bank $+6,567$ & Balance_GDP $=-4,771$ Economy $-0,606$ \\
M3_GDP $=11,547$ Bank $+72,277$ & Unempl $=-1,423$ Economy $+8,155$ \\
& Poverty $=33,323$ Economy+ 6,562 \\
& Debt_GDP $=-40,721$ Economy $+58,798$ \\
& PPI $=22,334$ Economy $+4,215$ \\
\hline
\end{tabular}

Source: authors' calculation.

Based on the conducted calculations, it is possible to make conclusions about the interdependence between the banking sector indicators and the state of the economy in the country. From the equations mentioned above, we can conclude that with the growth of the standardized hand in the banking sector by 1 , the economy increases by 0.7634 . Among the explicit indicators that can influence economic growth according to the strength of influence, it is possible to highlight the following: Interest rate (\%), Broad money M3 (current LCU, \% GDP), but not : the rate of growth of foreign exchange reserves, dynamics of exchange rate or volume of foreign direct investment in percentage to GDP. Thus, in terms of the central bank's influence instruments on economic growth, the most influential are the discount rate and the amount of money (M3 \% of GDP).

\section{Conclusion.}

The central bank plays an essential role in the monetary and banking systems of each country. It is responsible for maintaining financial sovereignty and economic stability in the country, both in developed and developing countries. The central bank issues currency regulates the volume of money supply, and controls interest rates in the country. Our work is directed around the importance of the regulator's role in ensuring its economic growth.

In this article, the relationship between the country's central bank and its economic development was considered. After reviewing the available scientific literature, it was discovered that the central bank, directly and indirectly, affects the country's economy through monetary policy instruments. Considering this fact, two groups of factors that characterize the banking sector and the country's economic development were formed. The structural equations method $\mathrm{o}$ is based on a diagram of paths, and the relationship between the regulator's activity and the state of the economy is confirmed. Through the canonical analysis, the role, power, and direction of the influence of latent variables on the central bank's performance indicators and the state of the economy were determined.

\section{References}

1. Adams, R. (2002) Economic Growth, Inequality and Poverty: Findings from a New Data Set, [in:] Policy Research Working Paper 2972. World Bank, February.

2. Ben S. Bernanke, Frederic S., Mishkin (1997) Inflation Targeting: A New Framework for Monetary Policy? The Journal of Economic Perspectives, 11(2), 97-116.

3. Berg, H.V., Schmidt, J.R. Foreing (1994) Trade and Economic Growth; Time series evidence from Latin America, University of Nebraska Lincoln, USA The Journal of International Trade and Economic Development, $3 / 3$.

4. Borio, C. (1997) The implementation of monetary policy in industrial countries: a survey, BIS Economic Papers, no 47.

5. Calderon, C., Chong, A., Loayza, N. (2000) Determinants of current account deficits in developing countries. Policy Research Working Paper. World Bank, 2398. 
6. Chen, J. (2012) Real Exchange Rate and Economic Growth: Evidence from Chinese Provincial Data (1992 - 2008), Paris-Jourdan Sciences Economiques Working Paper, http://hal.inria.fr/docs/00/66/74/67/PDF/wp201205.pdf, Access on: 09.03.2019

7. Choe, J.I. (2003) Do foreign direct investment and gross domestic investment promote economic growth? Review of Development Economics, 7(1), 44-57.

8. Debelle, G., Faruqee H. (1996) What determines the current account? IMF Working Paper, 58.

9. Deininger, Klaus, Lyn Squire (1996) New Ways of Looking at Old Issues: Inequality and Growth. Mimeo, World Bank, July.

10.Demirguc,-Kunt, A., V. Maksimovic (1998) Law, finance, and firm growth. Mathematical Finance, $53,2107-2137$.

11.Dominguez, Kathryn M. E., Linda L. Tesar (2006) Exchange Rate Exposure. Journal of International Economics, 68 (1, Jan), 188-218.

12.Fields, Gary (1989) Changes in Poverty and Inequality in Developing Countries. The WorldBank Research Observer, 4-2, 167-182.

13.Gallup, John Luke, Jeffrey D. Sachs, Andrew Mellinger (1998a) Geography and Economic Development, [in:] Annual World Bank Conference on Development Economics 1998. Washington, D.C.: World Bank, http://www.hiid.harvard.edu/pub/other/geodev.html.

14.Giles, D.E.A, Giles, F.A., McCann, E. Causality (1992) Unit Roots and Exported Growth: The New Zealand experience. The Journal of International Trade and Economic Development, November.

15. Hilbers, P., I. Otker-Robe, C. Pazarbasioglu, G. Johnsen (2005) Assessing and managing rapid credit growth and the role of supervisory and prudential policies. IMF Working Paper, 05/151.

16. Hussain, M. E., Haque, M. (2017) Empirical Analysis of the Relationship between Money Supply and Per Capita GDP Growth Rate in Bangladesh. Journal of Advances in Economics and Finance, 2(1), 54.

17.Kaminsky, G., C. Reinhart (1999) The twin crises: the causes of banking and balance of payments problems. American Economic Review, 89, 473-500.

18.Kandil, M., Greene, J. (2002) The impact of cyclical factors on the U.S. balance of payments. IMF Working Paper, 45.

19.Kemi, F. A., Dayo, B. O. (2014) Unemployment and Economic Growth in Nigeria. Journal of Economics and Sustainable Development. 5(4), 138-144.

20.Khan, M. S., Abdelhak, S. S. (2001) Threshold Effects in the Relationship between Inflation and Growth. IMF Staff Papers, 48(1), 1-21.

21.King, R. G., R. Levine (1993) Finance and growth: Schumpeter might be right. Journal of Financial Economics, 108, 717-738.

22.Kogid, M., Asid, R., Lily, J., Mulok, M., Loganathan, N. (2012) The Effect of Exchange Rates on Economic Growth: Empirical Testing on Nominal Versus Real. The IUP Journal of Financial Economics, 10 (1), 1-17.

23.Kumar, M., Woo, J. (2010) Public Debt and Growth. Working paper, IMF Publications.

24.Lawrence J.R. (1995) Housing Quality: An Agenda for Research. Urban Studies, 32 (10), 1655-1664.

25.Levine, R. (1997) Financial development and economic growth: views and agenda. Journal of Economic Literature, 35, 688-726.

26.Levine, R., N. Loayza, T. Beck (2000) Financial intermediation and growth: causality and causes. Journal of Monetary Economics, 35, 31-77.

27. Martin Ravallion, Shaohua Chen (1997) The World Bank Economic Review, Volume 11, Issue 2, 1 May, 357-382. 
28. Mckinnon, R. I. (1973) Money and Capital in Economic Development. The Brookings Institution, Washington, $D C$.

29.Ogunmuyiwa, M. S., Ekone, A. F. (2010) Money Supply - Economic Growth Nexus in Nigeria. Journal of Social Science, 22(3), 199-204.

30.Okun, A. M. (1962) Potential GNP: Its Measurement and Significance, [in:] Proceedings of the Business and Economics Section of the American Statistical Association. Washington, DC, American Statistical Association, 98-104.

31.Onafowora, O. A., Owoye, A., Nyatepe-Coo, A. (1996) Trade policy, export performance and economic growth: evidence from sub Saharan Africa. Journal of International Trade and Economic Development, 5, 341-360.

32.Pattillo, C., Poirson, H. Ricci, L. (2002) External Debt and Growth. IMF Working Paper.

33.Rajan, Raghuram, G., Luigi Zingales (1998) Financial Dependence and Growth. The American Economic Review, Vol. 88 (3), 559-586.

34.Roemer, Michael, Mary Kay Gugerty (1997) Does Economic Growth Reduce Poverty? CAER Discussion Paper, No. 5, Harvard Institute for International Development.

35.Saymeh, A. A. F., Orabi, M. M., A. (2013) The Effect of Interest Rate, Inflation Rate, GDP, on Real Economic Growth Rate in Jordan. Asian Economic and Financial Review, 3(3), 341-354.

36.Semuel, H., Nurina, S. (2015) Analysis of the Effect of Inflation, Interest Rates, and Exchange Rates on Gross Domestic Product (GDP) in Indonesia, [in:] Global Business, Economics, Finance and Social Sciences. Proceedings of the International Conference (GB15_Thai Conference). 20-22 February 2015, Bangkok, Thailand.

37.Smyth, D. and Hsing, Y. (1995) In Search of an Optimal Debt Ratio for Economic Growth. Contemporary Economic Policy, 13, 51-59.

38.Straßberger, M., Sysoyeva, L. (2016) Current developments in banking supervision with regards to financial stability. Wirtschaftsdienst, 2016, 96(7), 486-491.

39.Sweidan, O. D. (2004) Does inflation harm economic growth in Jordan? An econometric analysis for the period 1970-2000. International Journal of Applied Econometrics and Quantitative Studies, 1(2), 41-66.

40.Taylor, John B. (1993) Discretion versus Policy Rules in Practice. Carnegie-Rochester Conference Series on Public Policy, 39, 195-214.

41.Zhang, P., Ding, S., Wang, G., Zhou, D. (2001) An FDI approach for sampled-data systems. [in:] The American Control Conference. 